\title{
Exergy Analysis of 4.5mw Biomass Based Steam Power Plant
}

\author{
${ }^{1}$ R.Jyothu.Naik, ${ }^{2}$ B.L.V.S.Gupta, ${ }^{3}$ G.S.Sharma \\ ${ }^{I}$ P.G.Student Department of Mechanical Engineering V.R.Siddhartha Engineering college \\ ,Vijayawada,Andhra Pradesh,India \\ ${ }^{2}$ Assistant Professor, Department of MechanicalEngineering V.R.Siddhartha Engineering college, Vijayawada, \\ Andhra Pradesh, India. \\ ${ }^{3}$ Associate Professor, Department of MechanicalEngineering MVSR Engineering college,Hyderabad,Andhra \\ Pradesh,India.
}

\begin{abstract}
Exergy analysis provides a mean to evaluate the degradation of energy during a process, the entropy generation, the lost of opportunities to do work and offers an another approach for improvement of power plant performance.This paper present work Biomass based steam power plant(BBSPP) the results of an exergy analysis performed on a $4.5 \mathrm{MW}$ steam power plant in Karempudi.The results of the exergy analysis indicate that the boiler produces the highest exergy destruction .Exergetic efficiency is compared with Thermal Efficiency(based on Energy) and it is observed that thermal efficiency of the plant about 18.25\%andexergeticefficiencyis $16.89 \%$.
\end{abstract}

Keywords: Exergy, Anergy, Biomass, Boiler, Turbine, Condenser, Feed Pump.

\begin{tabular}{ll}
\hline NOMENCLATURE \\
$\mathrm{H}$ & Enthalpy \\
$\mathrm{S}$ & Entropy \\
$\mathrm{E}$ & Exergy \\
$\mathrm{Q}_{\mathrm{R}}$ & Heat Input \\
$\mathrm{Q}_{\mathrm{CH}}$ & Chemical Energy of Fuel \\
$\mathrm{EQ}_{\mathrm{CH}}$ & Chemical Exergy \\
$\nabla \mathrm{e}_{\mathrm{B}}$ & Loss of Exergy in Boiler \\
$\nabla \mathrm{e}_{\mathrm{T}}$ & Loss of Exergy in Turbine \\
$\nabla \mathrm{e}_{\mathrm{C}}$ & Loss of Exergy in Condenser \\
$\eta_{\text {th }}$ & Thermal Efficiency of the plant \\
$\eta_{\mathrm{e}}$ & Exergy efficiency of plant \\
$\eta_{\mathrm{b}}$ & Efficiency of boiler \\
\multicolumn{2}{c}{ Exergeticeffeciency of the boiler } \\
$\mathrm{f} \eta_{\mathrm{eb}} \quad$ 1.08(solid fuel as shown by szargut) \\
Subscripts (State Points in Rankine Cycle): \\
1.Boiler & 2. tubine \\
3.condenser $\quad$ 4.feed pump
\end{tabular}

\section{Introduction}

Biomass Based Steam Power plants use fuels like Rice husk, Groundnut shell, Fire wood, coconut and other Agro waste \& Municipal solid waste (instead of conventional fuels like coal ) burnt in biomass fired boiler to generate steam at high pressure. Due to the rapid depletion of conventional fuels there is increasing demand for using renewable sources of energy and use of biomass seems to be an alternative to conventional fuels in generating power. The object of this paper is to discuss Rankine Cycle and to introduce exergy analysis of Rankine cycle to enable us to find exergetic efficiency and component-wise losses. The analysis uses parameters of a working biomass based steam power plant of $4.5 \mathrm{MW}$ capacity.

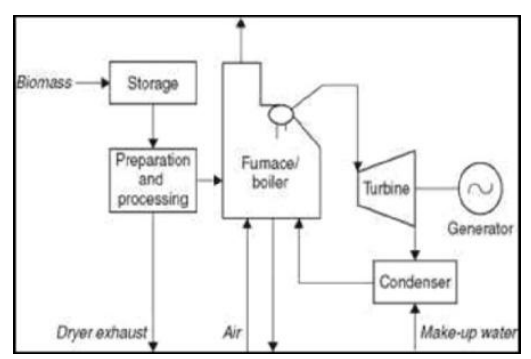

Figure 1: Layout of a BBSPP 


\section{Literature Survey}

Most of the plants are analyzed and reported in literature are pertaining to either plants of more than 100 MW capacity or it is less than 1MW capacity. Plants of the capacity less than $1 \mathrm{MW}$ are mostly of academic interest and outcome of the reports indicate the total efficiency. As per the recent studies conducted on exergy analysis of plants are either directly coal fired plants or large capacity gas turbine plants [Kotas]. As on today to overcome the fast depletion of fossil fuels and support the renewable energy options for powergeneration there is a scope for biomass based power plants.Biomass can be used for either direct combustion in the specially designed waste recovery boiler or can be converted into useful syn gas by Thermo chemical gasification. Gasification is again a differentstream of process where solid fuel is directly converted into gaseous fuel of mostly $\mathrm{CO}$ and $\mathrm{H}_{2}$. This gas has a lower calorific value due to dilution of Nitrogen in the gas [G.S.Sharma et al]. Direct firing of the biomass in the boiler for generation of the steam is a commercially viable option for power plants engineers. The reason for this statement is that only conventional fuel is replaced by biomass. The quantity of biomass may vary from conventional coal in the boiler as the calorific value of the biomass is less than coal. There are various aspects to be considered in direct firing of the biomass in boilers such as high moisture content of the fuel, corrosive ash content and emissions.

Most of the literature published claims the thermal efficiency of the thermal plants are about $33 \%$ in India where as in the global scenario it is as high as $45 \%$.Attaining higher efficiencies need investigation of available energy at all salient points of operation of the plant. The depletion of available energy (exergy) is due toincrease in entropy [van wylen] or more practically due to irreversibility in the thermodynamic system. This paper states the need of exergy analysis to BBSPP which helps in improving the efficiency of the plant

\section{Operating Parameters}

For exergy analysis, the following operating parameters are used.

Table 1 : Operating Parameters

\begin{tabular}{|l|l|l|l|}
\hline S.No & Component & $\begin{array}{l}\text { Pressure } \\
(\mathrm{bar})\end{array}$ & $\begin{array}{l}\text { Temperature } \\
\left({ }^{\mathrm{o}} \mathrm{c}\right)\end{array}$ \\
\hline 1 & Boiler & 80 & 280 \\
\hline 2 & Turbine & 65 & 485 \\
\hline 3 & Condenser & 0.89 & 50 \\
\hline 4 & Feed Pump & 0.89 & 100 \\
\hline
\end{tabular}

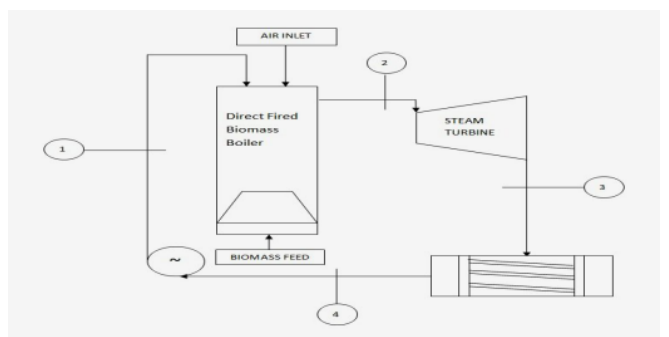

Figure 2: P\&I Diagram

\section{EXERGY ANALYSIS OF BIOMASS BASED STEAM POWER PLANT}

When we study a thermal system, we would like to know how good the system is and how much energy it consumes. For this purpose, we can imagine an ideal system i.e. a system that uses reversible processes and compare it with the actual system to find its performance. According to Second Law of Thermodynamics we understand that energy can be divided into 2 parts:

1. Available Energy (Exergy)

2. Unavailable Energy (Anergy)

A. Boiler

Combustion of fuel is highly irreversible process. Moreover, the heat transfer from the flue gases to the water takes place with a large temperature difference. Hence, heat transfer also is a highly irreversible process. Therefore, considerable degradation of energy takes place in the boiler.

The loss of exergy in boiler is given by

$\mathrm{Q}_{\mathrm{R}}=\mathrm{H} 2-\mathrm{H} 1$

$\nabla \mathrm{E}_{\mathrm{S}}=\mathrm{E} 2-\mathrm{E} 1$

$\mathrm{EQ}_{\mathrm{CH}}=\mathrm{F}^{*}\left(\mathrm{Q}_{\mathrm{CH}}\right.$

$\nabla \mathrm{E}_{\mathrm{B}}=\mathrm{EQ}_{\mathrm{CH}}-\nabla \mathrm{E}_{\mathrm{S}}$

$\eta_{\mathrm{B}}=\mathrm{Q}_{\mathrm{R}} / \mathrm{Q}_{\mathrm{CH}}$ 
$\eta_{\mathrm{EB}}=\mathrm{Q}_{\mathrm{R}} / \mathrm{EQ}_{\mathrm{CH}}$

$E^{*}{ }_{C H}($ fuel $)=\beta .(L H V)$
(6)

The Loss of exergy in boiler consists of 2 parts,

i.e.

1. Due to incomplete combustion and incomplete recuperation of flue gases.

2. The temperature restriction of steam restricts the maximum exergy that can be given to the steam.

The Boiler Efficiency is about $75.69 \%$. The

exergetic efficiency of the boiler is $70.08 \%$.

B. Turbine

The steam flowing through the turbine passages has to overcome friction. There is considerable turbulence in the high velocity stream. This results in loss of exergy. The efficiency of the turbine is the ratio of actual work done and the isentropic work done bturbine. The efficiency of the turbine comes out to be $88 \%$.

The loss of Exergy in the turbine is given by

$\nabla \mathrm{E}_{\mathrm{T}}=\left(\mathrm{E}_{2}-\mathrm{E}_{3}\right)-\mathrm{W}_{\mathrm{T}}$

\section{Condenser}

Large quantity of heat is removed from the condenser by cooling water. The heat rejected by the condenser is more or less worth less and cannot be judged for the performance of the condenser.

The Loss of Exergy in the condenser is given by

$\nabla E_{C}=E 4-E 3$

D. Feed Pump

Part of the work done by the pump is lost in friction. However pumping work itself is often negligible. Thus we assume the pumping losses to be negligible. The work done by pump is assumed to be zero.

\section{RESULTS}

Exergy analysis of a $4.5 \mathrm{MW}$ BBSPP is performed and exergy values at all locations are investigated. It is observed that exergetic efficiency of the overall plant is $16.89 \%$ and overall thermal efficiency is about $18.25 \%$. The difference of $1.36 \%$ is destruction of available energy is observed.

Table 2 : Properties Of Steam

\begin{tabular}{|l|l|l|l|}
\hline State & $\begin{array}{l}\text { Enthalpy } \\
(\mathrm{KJ} / \mathrm{Kg})\end{array}$ & $\begin{array}{l}\text { Entropy } \\
(\mathrm{KJ} / \mathrm{KgK})\end{array}$ & $\begin{array}{l}\text { Exergy } \\
(\mathrm{KJ} / \mathrm{Kg})\end{array}$ \\
\hline 1 & 1027.83 & 2.45 & 957 \\
\hline 2 & 3380.97 & 6.79 & 3178.5 \\
\hline 3 & 2402.9 & 6.85 & 2193.6 \\
\hline 4 & 401.3 & 1.23 & 366.06 \\
\hline
\end{tabular}

In exergy analysis of BBSPP the exergies of boiler, turbine, and condenser are calculated and their losses in exergy are calculated as shown in table 3 and 4. It is observed that maximum loss of exergy (Anergy) occurs at the boiler. The boiler losses can be minimized by using Losses can be still reduced when the pumping all relevant air condensation process, i.e. by maintaining low vacuum and dissociating gases in condenser, the losses can be still reduced if proper condensation of flue gases cooling is adopted.It can be seen that the maximum exergy destruction occurs in the boiler with a value of $49.17 \%$ of the totalexergy destruction. It seems obvious from the data in that the irreversibility associated with chemical reactionsis the main source of exergy destruction. 
Table 3 :Exergy and Anergy Calculations

\begin{tabular}{|c|c|c|c|c|c|}
\hline \multirow{2}{*}{$\begin{array}{l}\text { S. } \\
\text { No }\end{array}$} & \multirow[b]{2}{*}{ Components } & \multicolumn{2}{|c|}{ Condition } & \multirow[b]{2}{*}{$\begin{array}{l}\text { Exergy } \\
\text { Destruction }\end{array}$} & \multirow[b]{2}{*}{$\begin{array}{l}\text { Anergy } \\
(\mathrm{KJ} / \mathrm{Kg}\end{array}$} \\
\hline & & $\begin{array}{l}\text { Exergy } \\
\text { (Inlet) }\end{array}$ & $\begin{array}{l}\text { Exergy } \\
\text { (Outlet) }\end{array}$ & & \\
\hline 1 & Boiler & 6200.95 & 3151.51 & 49.17 & 3049.44 \\
\hline 2 & Turbine & 3151.51 & 2125.93 & 32.54 & 1025.58 \\
\hline 3 & Condenser & 2125.93 & 1312.07 & 38.28 & 813.86 \\
\hline 4 & Feed Pump & 1312.07 & 1037.83 & 20.90 & 274.24 \\
\hline
\end{tabular}

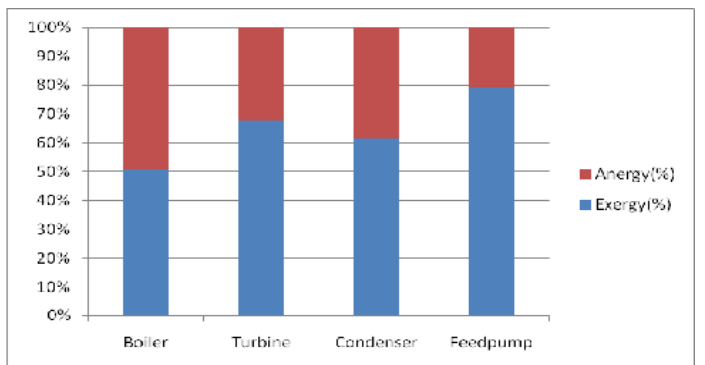

\section{Figure3:Graphical Representation of Exergy Destruction}

Table 4 : Overview Of Results

\begin{tabular}{|l|l|}
\hline Heat Supplied By Fuel $\mathrm{q}_{\mathrm{ch}}$ & $3680 \mathrm{KJ} / \mathrm{Kg}$ \\
\hline Exergy Supplied By Fuel eq & $3974.4 \mathrm{KJ} / \mathrm{Kg}$ \\
\hline Thermal Efficiency $\eta_{\mathrm{t}}$ & $18.25 \%$ \\
\hline Exergy Efficiency $\eta_{\mathrm{e}}$ & $16.89 \%$ \\
\hline Exergetic Efficiency of Boiler $\eta_{\mathrm{eb}}$ & $70.08 \%$ \\
\hline Total Loss of Exergy in Boiler $\nabla \mathrm{e}_{\mathrm{b}}$ & 2554.44 \\
& $\mathrm{KJ} / \mathrm{Kg}$ \\
\hline Loss of Exergy in Turbine $\nabla \mathrm{e}_{\mathrm{T}}$ & $126.25 \mathrm{KJ} / \mathrm{Kg}$ \\
\hline Loss of Exergy in Condenser $\nabla \mathrm{e}_{\mathrm{C}}$ & 1825.54 \\
& $\mathrm{KJ} / \mathrm{Kg}$ \\
\hline
\end{tabular}

\section{References}

[1] Kotas TJ. The exergy method of thermal plant analysis. London:Butterworths; 1985

[2] A.V. Bridgewater, Renewable fuels and chemicals by thermal processing of biomass, Chemical Engineering Journal, 91 (2003) 87102.

[3] Verkhivker G. P., Kosoy B. V., (2001). on the exergy analysis of power plants, Energy conversion and management 42, 2053-2059.

[4] Sengupta S., Datta A., Duttagupta S., (2007). Exergy analysis of a coal-based 210MW thermal power plant, International Journal of Energy Research 31, 14-28.

[5] Van wylen et al, "Statistical and classical Thermodynamics".

[6] IIT Bombay lecture notes .

[7] P.K. Nag, "Basic and Applied Thermodynamics," Tata McGraw-Hill, New Delhi, 2002.

[8] Gorji-Bandpy, VahidEbrahimian "Exergy analysis of a steam power plant: a case study", International Journal OfExergy, 2007.

[9] Bejan, A., Advanced Engineering Thermodynamics. New York: John Wily\& Sons, 1990.

[10] Szargut, J., Morris, D.R. and Steward, F.R. (1988). Exergy Analysis of Thermal, Chemical, and Metallurgical Processes, Hemisphere, 332 pp.New York. 